\title{
Overcoming the challenges of value chain development of some selected crops for poverty reduction in Nigeria: the entrepreneurial dimension
}

\author{
Zaman, Ezekiel Y*., Abdul, J. M., Otiwa, Godwin, Odey, Bernard O., Adaaja, Blessing O \&Raji, Umar. E \\ *Correspondence Author: Email- ezamanyuyu @ gmail.com \\ Authors are Research Fellows with the Trial Afforestation Research Station (TARS), Kaduna, Forestry Research Institute of \\ Nigeria (FRIN), Nigeria.
}

\author{
DOI: 10.31364/SCIRJ/v7.i1.2019.P0119609 \\ http://dx.doi.org/10.31364/SCIRJ/v7.i1.2019.P0119609
}

\begin{abstract}
The agricultural sector has been an engine of growth for the Nigerian economy with the crop sub-sector playing a dominant role, accounting for 90 percent of the sectoral output. But this seemingly substantial contribution is inadequate when juxtaposed alongside the potential of the sub-sector. In specific terms, of the 82 million hectares of arable land in Nigeria, only 34 million hectares are under cultivation with about 80 percent of the population employed in agriculture. The country's poverty rate is high (36.19 percent, as at 2013) which is largely accounted for by those in the rural areas and employed in agriculture. The annual food import bill has been high (\$4.2 billion), due to the short-fall between demand and supply of agricultural products, and is largely attributed to the low development of the value chains of crops. Equally, a large percentage of farmers in the country practice subsistence farming with little or no business approach in their production. This paper reviewed the challenges in the value chain development (such as poor or absent infrastructure, unsupportive laws and regulations, social barriers, inadequate financial support, poor access to information, market-related risk, and low bargaining power) of five selected crops: rice, wheat, maize, soybean and tomatoes, and suggested how they can be surmounted through enhancing the entrepreneurial capacity of farmers in the country for self-sufficiency in food production and extreme poverty eradication.
\end{abstract}

Key Words: Challenges, Entrepreneurship, Extreme poverty, Value-chain

\section{INTRODUCTION}

The agricultural sector has been an engine of growth for the Nigerian economy. The sector is made up of four subsectors namely crop production, livestock, forestry and fishing. The crop sub-sector did not just account for a greater proportion - 89 percent of the agricultural GDP growth of 4.1 per cent in 2010-2015, but was also the topmost of all the subsectors in the whole Nigerian economy in terms of contribution to GDP within the same period [1]; [2].

But over the years, the increase in output and growth has largely been attributed to expansion in cultivated area rather than from efficiency, due to the predominantly traditional feature of Nigerian agriculture [3]; [4]. Similarly, crop production has largely been commodity-based (with very low value-addition) rather than product-based. Given this low value addition, absence of certification and other associated problems such as poor quality of products, acceptability and pricing has been low locally and internationally. This has reflected on the low income generating and poverty reduction capacity for the sector. Among other approaches, value chain improvements in crop production are considered pivotal to improving income multiplier effects of agriculture as a whole on economic growth and development.

\section{Agricultural Value Chain}

A value chain describes the full range of value-adding activities required to bring a product or service through the different phases of production, including procurement of raw materials and other inputs, assembly, physical transformation, acquisition of required services such as transport or cooling, and ultimately responding to consumer demands [5]; [6]. Value Chains are mechanisms that allow producers, processors, buyers, and sellers (separated by time and space) to add value to products and services as they pass from one segment of the chain to the next, till the product gets to the final consumer [7].

Applied to agriculture, the concept of value addition is a vital component of the overall strategy for addressing postharvest losses, food security and global market competition. The processing of agro raw materials into various innovative products promotes market acceptability and gives the products high economic value which consequently brings higher income to the producer. The value chain perspective provides an important means to understand business-to-business relationships that connect the chain, mechanisms for increasing efficiency, and ways to enable businesses to increase productivity and add value [5]. It acknowledges that production must be linked to demand and the critical role of organizing the flow from farmer to consumer opportunities as illustrated on Figure 1. Agricultural value chain links the steps a product takes from the farmer to the consumer and includes input suppliers, production, processing, marketing and finance. Each player in the chain has a direct link with the next, to form a strong and viable chain[8]; [9].

\section{Agricultural value chain gaps}

Typically, a value chain brings about the creation of utility by various participants in the value chain until the product from the farmer/farm gate gets to the final consumer at the place, time, quantity and form he wants it. Any deviation or 
inability to meet these utilities entails a gap in the value chain. And any market-and growth-minded economy must strive to close such chasms. Gaps between potentials and realities must be continuously reduced or covered.

Although agriculture is a key economic sector in Nigeria, the value chain is highly underdeveloped. This gap explains why the country is a net importer of agricultural produce, with imports totaling NGN 630bn, the bulk of which is accounted by wheat ( $\mathrm{N} 165 \mathrm{bn})$, fish ( $\mathrm{N} 105 \mathrm{bn})$, rice ( $\mathrm{N} 75 \mathrm{bn})$, and sugar (N60bn). The country has an average total food import bill of $\$ 4.2$ billion annually [3]; [10]; [11]; [12].

This review examines how entrepreneurship can be harnessed to address the gaps in the value chain of the following selected crops namely: rice, wheat, maize, soybeans and tomatoes. These are the domestic priority crops as contained in the Agriculture Promotion Policy 2016-2018 [13]. There is a high demand for these crops as food staples or industrial raw material which is not met by supply. Utilizing the existing high potential of bridging the gap between in their production and value-added demand is therefore pivotal in attaining the policy's aim of resolving the four-pronged challenges of achieving food security, import substitution, job creation and economic diversification. The shortfall between demand and supply of these crops is presented on table 1 .

Given this scenario, the President Muhammadu Buhari Administration has mapped out policy strategies in the Economic Recovery and Growth Plan (ERGP) 2017- 2020 towards making Nigeria becoming self-sufficient in the local
Table1: Gaps in the demand and supply of five selected key crops in Nigeria.

\begin{tabular}{cccl}
\hline Crop & $\begin{array}{c}\text { Demand } \\
\text { (in } \\
\text { million } \\
\text { tons) }\end{array}$ & $\begin{array}{c}\text { Supply } \\
\text { (in } \\
\text { million } \\
\text { tons) }\end{array}$ & \multicolumn{1}{c}{ Remarks } \\
\hline Rice & 6.3 & 2.3 & $\begin{array}{l}\text { Insufficient supply } \\
\text { integration } \\
\text { Demand driven for } \\
\text { different types of wheat } \\
\text { (white, hard, durum etc) } \\
\text { for bread, biscuits and } \\
\text { semovita. }\end{array}$ \\
Wheat & 4.7 & 0.006 & $\begin{array}{l}\text { Limited imports required } \\
\text { but fluctuates due to feed } \\
\text { demand } \\
\text { Animal feed and protein } \\
\text { cost alternatively driving } \\
\text { demand. } \\
\text { Actual production is }\end{array}$ \\
Soybeans & 7.5 & 7.0 & $\begin{array}{l}\text { 1.5m ton but } 0.7 \mathrm{~m} \text { ton } \\
\text { due to post-harvest } \\
\text { losses. }\end{array}$ \\
\hline Tomatoes & 2.2 & 0.8 & 0.6 \\
\hline Source: FMARD, 2016 (The Agriculture Promotion Policy 2016 - 2020).
\end{tabular}

All of these determine costs and returns at each segment and ultimately defines the actors' profit margins as the product moves along the value chain.

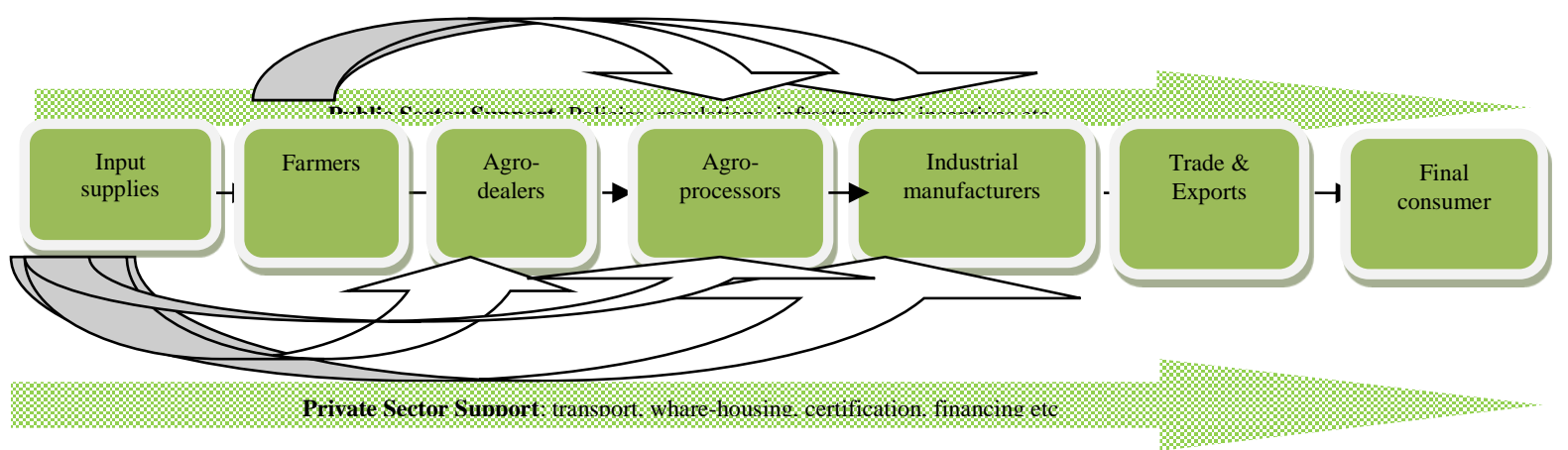

Figure1. Components of agricultural value chain (Adaptedfrom CBN, 2011;

NIDO, 2011)

production of tomato paste by 2017 , rice by 2018 , and wheat by $2019 / 2020$ [1].

However, it is important to note that gaps between the demand and supply of these crops are embedded in the gaps which exist at the various stages of their value chains. Several factors have been identified as barriers or challenges to the improvement in the value chain process. The constraints in Nigeria include: limited availability and access to resources, intra- and inter-firm organization, dearth in, and in the use of knowledge and technology, limited understanding and coordination at different level between actors, climatic factors, pests and diseases, poorly developed markets and the quality of public and private support services in transport, storage and finance sectors.
The implication is that if margins turn negative, the actors sooner or later may drop out of the value chain. If a whole segment of the value chain faces negative margins then the development of the value chain is seriously constrained [1]; [7]; [13].

Considering these constraints in Nigeria viz-a-viz the characteristic small-holder nature and low educational level of the majority of farmers in the country, the transformation of agriculture can be realized by creating an entrepreneurial environment that starts on the farm. There must be paradigm shift from the traditional philosophy and mode of production to a profit and growth-oriented model, through harnessing and enabling the entrepreneurial skill and spirit of smallholder farmers, particularly the young people in the rural economy.

\section{The value chains of rice, wheat, maize, soybeans and tomatoes in Nigeria}

\section{Rice value chain}

Rice grows all across Nigeria, but is mainly produced in the middle belt and northern states of Benue, Kaduna, Niger 
and Taraba, as well as the south eastern states of Enugu, Cross River and Ebonyi. Rice production in Nigeria has been unable to keep up either with increases in harvest area, or with increases in consumption, over the past forty years. More than 6 million tons of rice is consumed per year of which over half, or about 3.1 million tons, is imported despite a tariff of $70 \%$. Nigeria is the second largest importer of rice in the world. Rice is mainly imported from Thailand, Brazil, India, USA, and UAE. Because, Nigeria consumes parboiled rice largely in contrast to Benin Republic where white rice is preferred, and given that the latter charges a relatively small import duty of $12 \%$, the bulk $(85 \%)$ share of its parboiled rice imports is smuggled into Nigeria [14].

In order to reduce dependence on imports, the government of Nigeria had earlier set an ambitious target of achieving selfsufficiency in rice production by 2015 through the Agricultural Transformation Agenda (ATA) and rice sector policies. The Agricultural Transformation Agenda (ATA) had a target of achieving a production output 7.4 million tonnes of paddy, at an average yield of 4 ton/ha, and a processing capacity of 2.5 million tonnes of import quality milled rice processing capacity by 2015 [11]; [15].
Rice farmers tend to perform most of these functions, except milling, which is usually done by a cottage industry or large-scale rice mill. Threshing is usually done on the field either by machine or by hand, while drying is usually done on drying floors or tapelines off farm. Many farmers and farm groups are now acquiring mechanical threshers. Rice consumers are increasingly demanding quality polished rice without impurities. Thus, there is growing demand for modern cost effective threshers.

\section{Wheat value chain}

The increasing demand for wheat products (flour and flourbased foods), against a relatively low local production has made wheat become one of the most important agricultural commodities in need of accelerated local production.

As at 2015, Nigeria imported about 4.3 million metric tonnes of wheat at a cost in excess of $\$ 3$ billion. The wheat industry is an integral part of the country's food chain, producing flour for low cost convenient staple and baked foods.



Figure 2.Rice Value Chain in Nigeria

Source: UNIDO (2011).

Rice quality and standardization are not yet well developed in Nigeria because rice processing and milling are still primarily conducted at the cottage level. Although the Standards Organization of Nigeria (SON) is statutorily responsible for preparing the standards relating to products and for the certification of industrial products, the quality of rice milled and processed is not regulated based on standards.

The locally milled rice is contaminated by sand and stone particles, weed seeds, contain a lot of broken grains, and often poorly parboiled. Hence the grains have offensive odours, lack uniformity and consequently poorly accepted by the consumers, and therefore less competitive in local urban elite markets and internationally too [16].

The main actors in the Nigerian rice value chain actors are farmers, threshers, millers, polishers, wholesalers, retailers and importers (Fig. 2).
Wheat milling capacity was estimated at about 8 million tons in $2012 / 2013$, up from 6.6 million tons a year earlier, with average capacity utilization at $50 \%$.The industry is highly competitive, with the top players controlling over $70 \%$ of the market, reflecting an oligopolistic market structure [17].

Considering the gap between the demand and local production of wheat in Nigeria, the FMARD developed the country's Wheat Transformation Agenda (WTA) under the President Goodluck Jonathan administration's Agricultural Transformation Agenda (ATA). Amongst other initiatives, the WTA was pursued via a range of policies, aimed at reducing wheat consumption. These consisted of the inclusion of cassava flour in bread (set at a minimum of $5 \%$ to as much as $40 \%$ ), implementation of $15 \%$ levy on wheat importation as well as agricultural incentives aimed at spurring local wheat farming. The WTA 2017 target for local production of wheat was $1.5 \mathrm{~m}$ tonnes. The Government also expected to reduce 
wheat importation by $50 \%$ by 2017 alongside ensuring annual growth rate of local production from 2017 onwards projected at $20 \%$ [11]; [17].

As with the other agricultural value chains, the value chain of wheat (Fig. 3) consists of four basic components namely inputs, farm/farmers, processors and intermediaries.

\section{Maize Value Chain}

Nigeria is the largest maize producer in Africa. Maize is grown throughout the country, occupying the largest area of cultivated land [15]. Some regions are able to cultivate the crop two times a year, but cultivation is highest in the northern part of the country, especially in states such as Kano, Kaduna, Bauchi, Gombe, Adamawa, Taraba and Jigawa. Maize was harvested over an estimated area of 3.8million hectares during the 2015/16 cropping season. Nigeria presently produces about 4.27 million metric tonnes of maize annually.

About $50 \%$ of the maize produced is consumed by the animal feed sector, with poultry claiming as much as $98 \%$ of the total feed produced in Nigeria between 2005 and 2010.

\section{Soybean value chain}

Soybean is not a primary crop in Nigeria. The country has produced 300,000 to 600,000 metric tonnes of soybeans each year since the late 1980s. It is a relatively new crop in Nigeria, which is mostly cultivated in the North West, North East and North Central parts of the country.

\section{Tomato value chain}

Nigeria ranks as the 16th largest tomato producing nation in the world and has the comparative advantage and potential to lead the world in tomato production and exports. The production of tomatoes in Nigeria in 2010 was about 1.8 million metric tonnes, which accounts for about $68.4 \%$ of West Africa, $10.8 \%$ of Africa's total output and $1.28 \%$ of world output [19]; [20]. Tomato is an important component of the daily diet, consumed both fresh and in paste form. Main actors in the chain include input providers (seeds, fertilizer, pesticides, irrigation systems), producers, small-scale processors, and retailers and, to a limited degree, industries that engage in the production of tomato paste and canned tomatoes. Production is dominated by small to medium farmers that have reached a substantial level of market orientation. The major tomato producing states are Sokoto, Gombe, Benue, Kano and Yobe.

Over $45 \%$ (750,000 metric tonnes) of tomatoes annually produced in Nigeria is lost due to poor food supply chain management, price instability resulting from seasonal fluctuation in production and the supply preference of farmers and middle men to urban market than processors due to low farm gate price [19].

Tomato wastage occurs mainly at the processing, packaging and distribution stages. This is due to the poor processing technology, lack of good storage system and the transporting system used for the distribution of fresh tomatoes

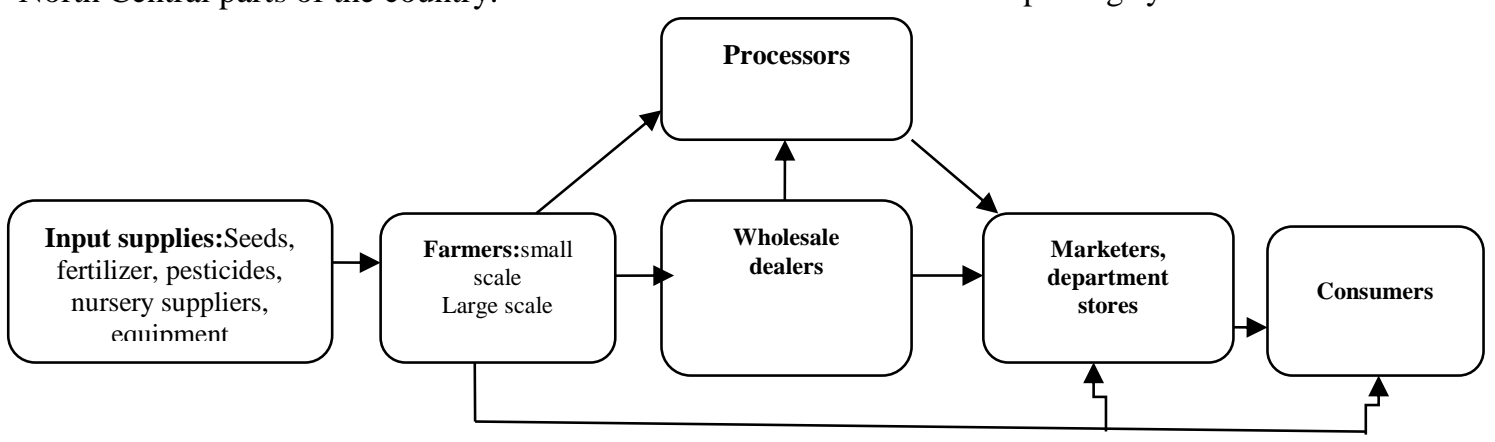

Figure5. Tomato value chain in Nigeria

Source: Adapted from, Ugonna and Onwualu (2015).

Nigeria is the largest consumer of soybeans in Africa. Nigeria's domestic production of soybeans has been increasing, but still does not meet the rapidly growing demand from the poultry industry and vegetable oil producers because it is largely produced by smallholder farmers, with less than 5 ha land area [18].

Soybean value chain (Fig. 4) follows a fairly linear path from input companies (seed, fertilizers, modern land preparing equipments etc.), through producers, traders up to processors and end product consumers.

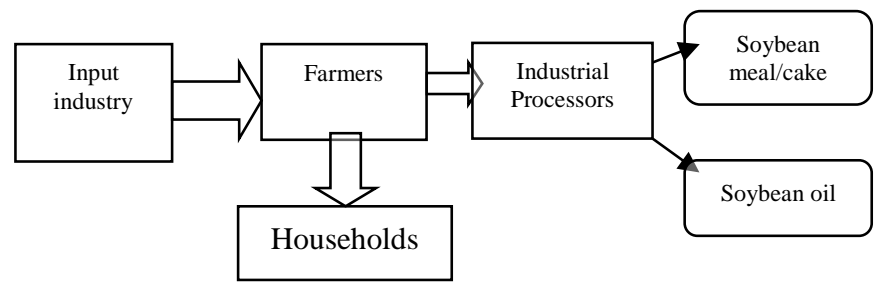

Figure 4: Soybean Value Chain

Source: UNIDO (2011)

\section{Development of the value chain of crops through entrepreneurship}

Value chain development is regarded as a market-led approach, as it helps satisfy the needs of the end consumer by fostering relationships and building trust among all stakeholders along a particular value chain to coordinate their activities. The approach emphasizes the point that one weak link can endanger the overall competitiveness of the value chain. It is an effective method for tracing product flows, showing the stages where value is added, and identifying key actors and their relationships in the chain [21].

The focus of value chain improvement in this paper is the farmer/producer link which is premised on the fact that a large percentage of farmers in Nigeria and those producing these selected crops in particular are small-holders with average farm size of 1.42 ha [22]. They generally have low capital (with limited access to fertilizer, irrigation, improved seeds, storage and processing technologies) poor market integration, low level of education, traditional in their way of life, making production decisions based on what they need and not on what is possible. They typically experience poor yields, and significant losses. As in other parts of the developing world, 
these farmers are yet see their farms as businesses. Long-term investment planning is not yet a priority. They are hesitant about diversifying to higher value products. They seem to be comfortable selling surpluses of their food crops. Expanding to cash crops is considered too extreme and involves risks that they are not willing to take [10] and therefore constitute a weak link in the value chain, which reflects on the low level of agribusiness.

Seventy-five percent of the world's poor live in rural areas and most are involved in agriculture. In the 21st century, agriculture remains fundamental to economic growth, poverty alleviation, and environmental sustainability [5]. In Nigeria, all poverty indices (headcount, gap and severity) have been found to be higher in the rural than in the urban areas for the years 2004, 2011, and 2013, and the vast majority of rural dwellers are farmers [23]. Even though, by the very nature of agriculture, most small farmers are entrepreneurs who make economic or business choices, manage risk, allocate resources, and combine farm and off farm activities to improve their livelihoods, their involvement in developed value chains and modern markets is minimal [10]; [22]. Hence, improving the entrepreneurial capacity of farmers is not just increasingly recognized as an effective approach for enhancing value chain competitiveness and generating growth, but central to reducing extreme rural poverty [5].

Entrepreneurship is the dynamic process of vision, change and creation. The farmer-entrepreneur should be able to envisage a clear picture in his mind of what is possible and the future he wants, his production decisions should be based on the knowledge of opportunities found in the market. The entrepreneurial farmer has the initiative, drive, capacity and ability to take advantage of opportunities to make profits [21]; [24].

But while farmer-entrepreneurs are traditionally free and independent, they do not work alone in the modern context. They operate in a complex and dynamic environment. They are part of a larger collection of people including other farmers, suppliers, traders, transporters and processors, each of whom has a role to play in the ever-developing modern markets and value chains [22]; [25]. Hence, if gaps in the production levels of rice, wheat, maize, soybeans and tomato are to be filled in Nigeria, a paradigm shift in the entrepreneurial mindset and conduct of farmers must be improved upon. Value chain development cannot significantly come from outside the chain, but rather requires the initiative of private entrepreneurs who take action in the business processes in the various segments of the chain, and also in the coordination between those processes, since there is a strong interdependence between the processes in the various segments of the chain [7].

\section{Improving the entrepreneurial capacity of small farmers for value chain development}

A range of barriers must be addressed in order to create and maintain a favourable environment for entrepreneurship development of small farmers as active participants in the value chains of these selected crops in Nigeria. These barriers and challenges are poor or absent infrastructure, unsupportive laws and regulations, social barriers (especially to women), inadequate financial support, poor access to information, market-related risk, low bargaining power, vulnerability to economic shocks, inadequate training facilities, low level of support services and trained extension staff [24].

Overcoming entrepreneurial barriers for value chain development will entail the following measures [7]; [10]; [14]; [26]; [27]; [28]:

i. Government creating the enabling business environment through provision of infrastructure, supportive laws and regulations.Often, what is blocking starting and growing profitable farm businesses is basic infrastructure. Simple things, such as poor roads leading to markets, inadequate storage and market facilities, and even irregular supplies of electricity create very real and practical barriers to developing farm businesses. Equally, governments at various levels need to implement the Agriculture Promotion Policy (APP) 2016-2020, which is built on the Agricultural Transformation Agenda (ATA), anchored on the guiding principles of considering and treating agriculture as a business, value chain approach, and market orientation with enabling laws and regulation. Land tenure and ownership, banking laws, trading, regulations, business and tax laws are some of the more common barriers that help or limit the development of successful farm businesses. Discriminatory practices which restrict women workers to certain nodes of the chain (such as processing and packaging) that require relatively unskilled labour, reflecting cultural stereotypes on gender roles and abilities, land ownership and legal status of women should be checked.

ii. Equipping farmers with business skills. Training farmers on "farming as a business" emphasizes a shift from farming for subsistence, to farming for profit and improved livelihoods. But, field or extension agents are often trained in production but not business management, and lack the skills to help farmers plan their enterprises. A paradigm shift is therefore necessary for their training, to equip them to provide farmers with appropriate-level analytical skills and business management tools which will help them to make decisions based on business principles, thereby decreasing costs and risks, and increasing profits.

iii. Capturing value within the value chain. Armed with the right business attitude, producing for the market is the first response of farmer entrepreneurs to the opportunities found along the value chain. These farmers will want to diversify their livelihoods to make them more sustainable and more profitable. One way to do this is by capturing value within the value chain such as selling their regular fresh produce directly to consumers.This requires greater understanding and knowledge of value chains and their different elements. It requires a plan for participating further down the value chain. Instead of producing commodities that are homogenous, farmers produce commodities that are differentiated such as organic fruit, a unique type of meat or other specialized products for a limited niche market. Another way of adding value is to enter into production and marketing contracts.

iv. Enhancing and managing efficiencies in production. Farmer-entrepreneurs need to be skilled at finding and using opportunities to expand their businesses. But they also need to be efficient in utilizing resources, and in transporting and marketing produce which could involve risk sharing by reduction of ownership costs. An example is sharing machinery ownership to reduce ownership costs, and benefit from better mechanical technology. This shared ownership 
agreements work well among farmers who have similar sized farms and produce similar products.

v. Adopting new technologies and innovation. New technologies are needed in order to adapt to a changing economy and a changing market. Farmer entrepreneurs should not only be consumers and users of these technologies but also active participants in designing, testing, adapting and introducing them to the farming system. This will require training them to know how these innovations work to improve their output and profits.

vi. Sustainable land management. Land constitutes the foundation of crop production more than for any form of businesses. While it is tempting to produce as much as possible over the short-term, a successful farmer-entrepreneur knows that the value of his land lies in its ability to continue producing profitably for generations. It is therefore pertinent that a re-awakening should be pursued in the entrepreneurial spirit in farmers for natural resource sustainability.

vii. Trustworthiness and respect in business. The longterm success of any business depends on it being conducted with trustworthiness and respect. This implies fair dealing, greater transparency and the building of trust between fellow producers, members of producer organizations, input suppliers, buyers, consumers and other businesses along the value chain. These qualities assure partners along the value chain that farmers are reliable, that their deeds match their words and that they respect everyone with whom they work. Standards for product quality must be adhered to at all times.

viii. Promoting group entrepreneurship. Some farmers are so poor that that they will individually be unable to make or reap any benefits from the ever evolving market chains. Hence, group entrepreneurship remains the most feasible option so that a group of likeminded farmers willing to work together can establish a joint enterprise. This often requires support from extension workers to organize the group and facilitate linkages along the value chain. The challenge is to know when to stop their support and hand overall management and entrepreneurship functions to the group.

ix. Managing farm businesses according to a long-term plan. Farmers face daily pressures as they operate the farm business and are often required to make many immediate decisions. But, for an entrepreneurial farmer, these decisions need to be made within a broader vision that guides the sustainable development of the business. Farmers must ensure that they are managing their farm businesses with a long term plan for the business so that it stays on course and its direction is not determined by day-to-day decisions.

\section{Conclusion}

Value chain development of maize, rice, wheat, soybeans, and tomatoes and other crops in Nigeria is a pre-requisite to reducing the gaps between their demand and supply as well as reducing post-harvest losses, and seasonal glut. This will help in uplifting the vast majority of small-scale farmers out of extreme poverty. But, smallholder farmers would have to be empowered to operate as entrepreneurs. This includes negotiating for good market prices to build viable smallholderbased business models. The narrative about smallholder farming will have to reframed, positioning smallholder farming as viable enterprise and enabling smallholder farmers as entrepreneurs and businessmen in charge of their destiny.

\section{References}

[1] FGN. Economic Recovery and Growth Plan 2017-2020. Prepared by Federal Ministry of Budget and National Planning, Federal Republic Of Nigeria, 2017.

[2] NBS. Nigerian Gross Domestic Product Report Q4 Report 2016. National Bureau of Statistics, Abuja, Nigeria, 2017, 138pp

[3] PWC. Transforming Nigeria's agricultural value chain: a case study of the cocoa and dairy industries. PricewaterhouseCoopers (PWC), Limited, Nigeria, 2017.

[4] Eboh, E., M. Oduh and Ujah, O. Drivers and sustainability of agricultural growth in Nigeria. AIAE Research Paper 8. 2012, African Institute for Applied Economics, Enugu. N

[5] Webber, M. C. and Labaste, P. Building Competitiveness in Africa's Agriculture: A guide to value chain concepts and application. The World Bank, Washington DC, USA, 2010.

[6] Kaplinsky and Morris. A Handbook for Value Chain Research, 2002, pp. 46-47.

[7] UNIDO. Pro-poor value chain development: 25 guiding questions for designing and implementing agro-industry projects. United Nations Industrial Development Organization (UNIDO). Vienna, Austria, 2011.

[8] NAIC. Insurable Risks in the Agricultural Value Chain. http://www.naic.gov.ng/news inside/insurable-risks-in-theagricultural-value-chain accessed September 5, 2017 @6:22am).

[9] Onwualu, A.P and Olife, I.C. Towards a sustainable value chain approach to agricultural transformation in Nigeria: the imperative of endogenous agricultural machinery development. Journal of Agricultural Engineering and Technology (JAET), No.21, vol. 1, 2013.

[10] Nwuneli, N., Diaw, A., Kwadzokpo, K andElbehri, A. The role of the private sector and the engagement of smallholder farmers in food value chains: initiatives and successful cases from Nigeria, Senegal, and Ghana. In: Rebuilding West Africa's food potential: Policies and market incentives for smallholderinclusive food value chains,Elbehri (ed.), 2013, pp. 187- 210. Published by FAO and IFAD, Rome.

[11] FMARD. Investing in Nigeria's agricultural value chains. Being a paper presented by Dr. AkinwumiAdesina, Minister of Agriculture and Rural Development Presented at the Bank of Industry's Nigerian Investment Forum, London, 2012.

[12] CBN, Integrating Nigeria's agricultural and financial value chains: the role of NIRSAL (Nigeria Incentive Based Risk Sharing for Agricultural Lending). Published by Central Bank of Nigeria (CBN), 2011

[13] FMARD. The Agriculture Promotion Policy (2016-2020): building on the successes of the ATA, closing key gaps. Federal Ministry of Agriculture \& Rural Development (FMARD) Abuja FCT, Nigeria, 2016 48p.

[14] Grow Africa. Developing business skills in smallholder farmers as a basis for income growth. Grow Africa Smallholder Working Group Briefing Paper, 2017.

[15] PARI. Nigeria: potentials and possibilities for German collaboration in agriculture. Programme of Accompanying Research for Agricultural Innovation (PARI), 2015.

[16] IFDC. Study of the domestic rice value chains in the Niger Basin of Mali, Niger, and Nigeria, West Africa, 2008.

[17] KPMG Nigeria. Wheat-based Consumer Foods in Nigeria. KPMG, 2016 
[18] Business Day Media. Nigeria Agric Sector Report (Crop Production) 2015. Business Day Research and Intelligence, a unit of BusinessDay Media Limited, Nigeria, 2015.

[19] Ugonna, C. U; Jolaoso, M. A. andOnwualu, A. P. Tomato value chain in Nigeria: issues, challenges and strategies. Journal of Scientific Research \& Reports, No. 7, vol.7, 2015, pp.501-515.

[20] FAO. FAOSTAT, 2010. Available: http://faostat.fao.org

[21] Joshi, S. R; Rasul, G; Shrestha Joshi, A. Pro-poor and climate resilient value chain development. operational guidelines for the Hindu Kush Himalayas. ICIMOD Working Paper 1, 2016.

[22] Kahan, D.. Entrepreneurship in farming. Published by Food and Agriculture Organization (FAO), Rome, 2013,129pp.

[23] World Bank. Poverty Reduction in Nigeria in the Last Decade. https://openknowledge.worldbank.org/handle/10986/25825, 2016, (accessed February 23, 2017).

[24] Nzewi, H.N; Onwuka, E. M. and Onyesom, M. Entrepreneurship evolution and the growth of small scale businesses in Nigeria. Journal of Business and Economic Development. Vol. 2, No. 3, 2017.

[25] Achancho, V. Review and analysis of national investment strategies for agricultural policies in Central Africa: the case of Cameroon. In: Rebuilding West Africa's food potential: Policies and market incentives for smallholder-inclusive food value chains,Elbehri (ed.), 2013, 117- 149. Published by FAO and IFAD, Rome.

[26] Igbokwuwe, M.C., Essien, B. A and Agunnanah, M. U. The Imperatives of Nigerian agribusiness: Issues and challenges. Science Journal of Business and Management, vol. 5, 2015. pp 7-10.

[27] Agriculture for Impact. Small and growing: Entrepreneurship in African agriculture. A Montpellier Panel Report, 2014, Imperial College, London, United Kingdom.

[28] FAO-ILO-IFAD. Agricultural value chain development: threat or opportunity for women's employment? Gender and Rural Employment Policy Brief No. 4, 2010. 